The Quarterly Journal of Austrian Economics

Volume 24 | NO. 1 | 41-78 | SpRING 2021 WWW.QJAE.ORG

\title{
The Illusions of INFLATION Targeting, with an Application TO UKRAINE
}

\author{
Nikolay GertcheV*
}

Jel Classification: E02, E14, E31, E42, E58, N10, Y10

Aвstract: This article reviews the analytical justification, the theoretical content, and the practical experience of inflation targeting, which has become the standard framework for monetary policy. It shows that due to the inflation-targeting literature's neglect for the money demand as part of the monetary relation that drives price determination, it provides a distorted theoretical account of the most basic relations in a monetary economy and an illusionary vision of what a modern central bank could achieve. The last section of the article uses the recent monetary history of Ukraine to illustrate the pitfalls and illusions of inflation targeting.

\section{INTRODUCTION}

Three renowned economists have declared recently that "infla1 tion-forecast targeting can be considered the state of the art for monetary policy" (Adrian, Laxton, and Obstfeld 2018, 14). Others have seen in inflation targeting (IT) a consistent and durable

\footnotetext{
*Nikolay Gertchev (ngertchev@gmail.com) holds a $\mathrm{PhD}$ in economics from the University of Paris II Panthéon-Assas and is currently based in Brussels, Belgium, where he works for an international organization. The author is grateful to an anonymous referee for his very useful comments.
} 
standalone international monetary system in which the key players, i.e., the central banks, "are now more independent, accountable and transparent than under Bretton Woods" (Rose 2007, 671). One of its chief theoretical advocates has concluded that IT is just the best manner which humanity has discovered so far to conduct monetary policy: "I believe it fair to say that never before in monetary history has an incentive system been set up with such strong incentives for optimal monetary policy decisions" (Svensson 1999, 633).

After the central bank of New Zealand adopted IT in early 1990, six other central banks in developed countries switched to this policy framework in the next four years. In the aftermath of a first academic conference that reviewed the experience with IT in 1994 and thanks to increased interest and research in IT by the International Monetary Fund (IMF) since 1997, thirteen central banks had moved to IT by the year 2000. Without including the euro area, which can be seen as a de facto case of IT, the IMF counted forty-one independent countries with an inflation-targeting framework in 2018 (IMF 2019, 7). Although twenty years ago it was indeed "too early to offer a final judgment on whether inflation targeting will prove to be a fad or a trend," the evidence nowadays undoubtedly shows that IT has gained overwhelming dominance (Bernanke and Mishkin 1997, 114). The success of this type of monetary policy, in terms of persistent and growing attractiveness for modern central banks, calls for an explanation. What are the specific goals and means of IT that account for its distinctiveness? Is its success due to a fundamental and innovative breakthrough in monetary theory? This article purports to provide answers to such questions.

The first section presents the standard definition, justification, and performance assessment of inflation targeting. The review of the various strands of literature distills the theoretical underpinnings of IT. The second section assesses the analytical foundation of IT from the angle of the Misesian theory of money, with special emphasis on the demand for money and the modern-day multiplicity of currencies. It concludes that the advocacy for IT is fundamentally flawed because of its neglect for the theoretical relevance of the pivotal concept of money demand. Because of this serious theoretical failure, IT can hardly be considered as an outgrowth of monetary theory at all. At best, it should be perceived as alleged guidance, clothed in the pretense of scientific knowledge, 
for the bureaucratic management of a central bank. The third and final section reviews, from that standpoint, the recent experience with IT in Ukraine.

\section{THE PRACTICE AND THEORY OF INFLATION TARGETING}

Inflation targeting is canonically defined as a framework or strategy for the conduct of monetary policy that comprises five elements (Mishkin 2004, 1). First, monetary policy is committed to the overarching, if not exclusive, goal of price stability, understood as a constant positive inflation rate, measured by historical changes in the consumer price index (commitment). ${ }^{1}$ Second, the monetary authority publicly announces a medium-term numerical target, with or without bands, for the inflation rate (target). Third, to achieve this target, the central bank regularly determines its policy interest rate based on a large information set primarily focused on, but not limited to, a formal inflation rate forecast model (instrument). Fourth, the central bank communicates transparently and periodically on its objectives and informed decisions (transparency). Fifth, the monetary authority is held accountable, either formally or with a public stake in its reputation, for the effective outcome of the inflation rate (accountability). There is an intimate link between the last two elements, as gains in accountability critically depend on the effectiveness of transparency. The second and third elements operationalize the conduct of monetary policy and in relation to the first one determine the institutional credibility of the central bank.

Conceptually, IT provides a structured approach to what a central bank should do in the post-Bretton Woods world of multiple money producers. It is a response to the failure of many central banks to produce money with a relatively stable purchasing power. Recurrent currency devaluations in the case of fixed exchange rates and continuous depreciations in the case of floating exchanges have been alerting the public at least since the

\footnotetext{
${ }^{1}$ This is also the sense in which this article uses the word inflation, in striking opposition to the admitted Austrian definition of inflation as any increase in the money supply beyond what it would have been in the free market, i.e., "the process of issuing money beyond any increase in the stock of specie" (Rothbard 2009, 990).
} 
early 1970s about the poor performance of the domestic central bank. Thus, IT emerged in the 1990s as a practical solution for central banks in search of existential revival.

\section{The Intellectual Roots of Inflation Targeting}

Developments in economic theory in the 1970s and 1980s seriously challenged the conventional Phillips curve view according to which monetary policy can achieve higher growth and lower unemployment through a tradeoff against higher inflation. The challenge came out of macroeconomists' interest in individual actions, notably as informed by their judgment about the future state of the economy. Thus, the formal integration in the analysis of inflation expectations concluded that money is neutral in the long run, in the sense that increases in the money supply have a lasting impact on prices and nominal variables only, with no effect on real output and employment (Friedman 1968). The power of this conclusion, which derives exclusively from the focus on expectations, led to stronger attention to expectations themselves. Economists from the entire intellectual spectrum quickly admitted that the assumption of choice rationality, i.e., of individuals' optimizing behavior, necessarily implied rationality of the formation of their views and opinions about the future. Thus, the assumption of rational expectations (Muth 1961) — that economic actors form their beliefs about the future based on all relevant information with respect to the causal relations in the economy, to the policies pursued by the authorities, and to the economic models and theories that underpin these policies-became the new norm. This so-called rational expectations revolution (Begg 1982) radicalized the revised view of the expectations-augmented Phillips curve, in particular, and of the potency of economic policy in general.

One of the most relevant pieces of the economic agents' information set for forming their expectations is the very model used by the economist to describe the functioning of the economy. This congruence between the assumed causal relationships between economic variables and the individual belief in these relationships leads to the self-validation of the assumed hypothetical model. Hence, rational expectations became a modeling tool that serves the purpose of proving the formal validity of the model's conclusions (Gertchev 
2007, 326). As a result, economic science further disintegrated into separate schools, each defined by its own set of auxiliary assumptions. TheNew Classics, who emphasize the lack of any friction and therefore the permanent and instantaneous clearing of all markets, conclude what is already implied by these assumptions - that monetary policy is inefficient at any moment, hence including in the short run (Lucas 1972; Sargent and Wallace 1975). The broader implication is that if discretion does not work, then monetary policy should follow a rule (Kydland and Prescott 1977). The New Keynesians, who assume a noncompetitive, sticky, or monopolistic price-setting mechanism, allow for a lag in the adjustment between economic variables, thereby creating room and scope for a well-designed policy. Moreover, the temporal lag in the New Keynesian version of the Phillips curve triggers an interpretation of current inflation as causally determined by future inflation expectations. Therefore, if a central bank aims to control inflation, it must first control inflation expectations, for which a credible commitment to a simple rule is most appropriate.

Essentially, inflation targeting is rooted in this theory-informed belief in the virtues of a rule-based monetary policy. It is in this context that the five aforementioned framework elements are best understood. Before proceeding to a presentation of the targeting rule itself, it is expedient to make two additional points on the choice of the target and of the instrument. First, without ever discussing details about the principles that should guide the numerical determination of the inflation target, advocates of IT simply admit that a low positive inflation rate should be pursued: "It seems clear that an inflation target of zero or near zero is not desirable for several reasons" (Bernanke and Mishkin 1997, 110; our emphasis). Following a very succinct discussion according to which i) inflation figures are overstating actual inflation, ii) too low inflation worsens the allocative efficiency of resources if nominal wages are rigid, and iii) deflation is bad, the IT advocates openly acknowledge that "Indeed, a potentially important advantage of inflation targeting is that it provides not only a ceiling for the inflation rate, but also a floor" (ibid., 110). Thus, what seems clear, indeed, is that IT is premised on a strong proinflation bias. ${ }^{2}$ ${ }^{2}$ Only Frömmel (2019) has raised the question of the most consistent rationalization
of the inflation target value itself. Within a Hayekian intellectual framework, he 
Second, with respect to the choice of the monetary policy instrument, proponents of IT consider the deregulation of the financial sector to have compromised the stability of the relation between the supply of and demand for money (Debelle 1997, 6). Due to the resulting volatility of "money velocity," there is no longer an empirically exploitable link between changes in the supply of money and the inflation rate (Mishkin 2004, 28). Hence, the choice of the money supply and of monetary aggregates as the operational intermediate target by the central bank appears impractical and unfit (Svensson 1997, 8). Rather, the central bank should strive to control the interest rate, in such a way that "inflation targeting provides a nominal anchor for policy and the economy" (Bernanke and Mishkin 1997, 108; our emphasis).

\section{The Theoretical Optimality of Inflation Targeting}

The rationalization of IT as the most optimal conduct of monetary policy relies on two building blocks: the so-called transmission mechanism and the minimization of an objective loss function.

The transmission mechanism is a depiction of the relevant causal relationships that describe the functioning of a monetary economy. The advocates of IT borrow this description from an alleged "conventional wisdom [which] appears to grow increasingly dominant" (Svensson 1999, 609). De facto, the economy is depicted in line with the tenets of a standard macroeconomic aggregate supply and aggregate demand model in the New Keynesian fashion. In such a model of the closed economy, monetary policy affects aggregate demand via its impact on the interest rate "and possibly on the availability of credit" (ibid., 609). Then, the effect on inflation stems from the aggregate supply, which is an expectations-augmented Phillips curve. This expectations channel is critical, as "[it] allows monetary policy to affect inflation expectations which, in turn, affect inflation, with a lag, via wage- and price-setting behaviour" (ibid., 609). In the open economy, expected and induced changes in the exchange rate are additional channels of transmission for monetary policy, as they either contribute to aggregate demand or directly impact the prices of goods (Svensson 2000, 158).

argues convincingly that monetary policy should target a negative inflation rate, equal to the opposite of the growth rate. 
This standard macroeconomic model has two remarkable implications. First, it manages to abstract from a detailed analysis of the monetary equilibrium. In particular, it ignores the role of the supply of and demand for money in the determination of monetary prices. Thus, it is questionable whether the very foundation of IT belongs to monetary theory at all. The most vocal theoretician of IT has actually acknowledged this peculiar feature: "In this view of the transmission mechanism, it is apparent that, perhaps somehow paradoxically and heretically, money only plays a minor role" (Svensson 1999, 610). Second, as an explanation of the factors that drive general changes in monetary prices is needed nevertheless, this explanation is provided by the modern infatuation with expectations. Hence, inflation expectations become the cornerstone of both theorizing about inflation and monetary policy.

The second building block of IT exemplifies this last point. In opposition to an instrument rule, such as the Taylor rule, which links the policy interest rate to some economic factors according to a deterministic reaction function, a targeting rule links the policy instrument to the minimization of a loss function. The loss function grows when inflation deviates from the target, and it can integrate deviations from other policy goals too, such as of output from its potential or of the exchange rate from its target or its volatility, etc. Strict IT includes only inflation deviations in the loss function. Flexible IT accounts for other potential goals of monetary policy. One way or another, the loss function is minimized when the actual inflation rate is at or very close to the targeted inflation rate. Now, faced with this tautology already implied in the very notion of inflation targeting, what should a central bank do in practice, especially given that according to the transmission mechanism it has no direct control over inflation?

The proposed solution consists of the central bank setting its policy rate at such a level that its own inflation forecast, conditioned by the formal macroeconomic models developed by its research department and based on any other relevant information, moves closer to the inflation target: "As emphasized in Section 2, using conditional forecasts as intermediate target variables is arguably the most efficient way of implementing monetary policy, since it can be interpreted as implementing first-order conditions for a minimum of the loss function, using all relevant information" (Svensson 1999, 
627). Therefore, inflation-forecast targeting becomes the operationalized real-world version of the theoretical IT. Since, allegedly, what matters for actual inflation are the inflation expectations of money users, the central bank must then engage in an intense communication campaign to engineer a congruence between modeled expectations, i.e., its own forecasts and projections, and real-world expectations, i.e., the public's actual beliefs. This includes the regular publication of inflation reports, of the central bank's updated forecasts and of the reasons that underpin its effective policy decisions.

Hence, IT boils down to the regular and yet nonmechanical setting of the policy interest rate, based on a large set of data and informed justifications. In recognition of the simplicity of this evident fact, some economists prefer to consider IT as a case of "constrained discretion" rather than a firm monetary rule (Bernanke and Mishkin 1997, 106; Kim 2011). What this view implies is that IT epitomizes the notion of an independent central bank in search of reputation and credibility, in the sense of covering its interest rate policy decisions with the mantle of scientism. The very fact that the optimizing approach takes the inflation target for granted ${ }^{3}$ best reveals the fictitiousness of the entire approach. The true issue with respect to optimality is the optimality of inflation itself. This, however, is a question that the supposedly optimal IT never raises. The unavoidable conclusion is that the true contribution of IT has been to rationalize the operational independence of modern central banks in terms of controlling the policy interest rate. In short, IT has become so popular, because it provides both a raison d'être and a modus operandi to central bankers.

\section{Performance Assessment of Inflation Targeting}

Central banks could not have embarked on IT so overwhelmingly had it failed to deliver on the promised results. Naturally, economists focused their attention on assessing its performance and the possible link to institutional prerequisites or other conditions. Interestingly, even though the reviews of IT experiences do not

\footnotetext{
${ }^{3}$ The restatement of the 2 percent inflation target as a goal "over the longer run" by the Fed as of August 27, 2020, illustrates the arbitrariness of the target.
} 
reach consensus on the materiality of macroeconomic benefits, they manage nevertheless to issue a rather favorable overall assessment.

As a starting point, all performance reviews recognize that IT has been successful in reducing the inflation rate. However, this temporal correlation only begs the question of whether a systematic underlying causality is at work. The IT literature has proved especially inventive in the variety of its responses. A very early review concluded that IT "is useful for those countries which may lack anti-inflation credibility" and that subsequently IT "is not necessarily appropriate for all countries" (Debelle 1997, 21 and 29). This is an open recognition that IT is just a tool to set up a fully fledged central bank in control of an independent monetary policy. IT becomes instrumental in producing "a convergence of central bank behaviour to that of the Bundesbank," which itself needs no IT to gain its independence and credibility (Neumann and Hagen 2002, 136). Thus, even though the "evidence does not support the claim that IT is superior to strategies that focus on monetary aggregates," it matters because it helps low-credibility central banks gain in reputation (ibid., 144).

Various econometric techniques, correcting for the resulting self-selection bias, helped reassess the evidence on macroeconomic performance in terms of reduced inflation rates, lowered inflation volatility, potential output gap, or even interest rate stability. The results are rather unanimous in concluding that IT in itself does not improve the economic performance of a country (Ball and Sheridan 2003, 17; Lee 2011, 396). Yet, in line with the relativism of methodological positivism, no firm conclusion is drawn. First, it is pointed out that the lack of a clear positive link between IT and macroeconomic performance implies in no way that IT is harmful. Second, if the available data has not yet confirmed a positive causal relationship, this would only mean that the test has not been conclusive and that a firm conclusion would require more data: "Thus a paper that replicates this study in 25 or 50 years may find ample evidence that targeting improves performance" (Ball and Sheridan 2003, 17). The authors admit, however, that if IT central banks do not bring about better macroeconomic results than non-IT central banks, this might suggest that both groups are pursing the same interest rate policy, despite their formally different policy frameworks. This in fact reinforces the view that IT is but a device for weak central banks to acquire independent political stance. 
From that perspective, the macroeconomic success of IT is necessarily related to the broader institutional and policy setup in a country. The International Monetary Fund (IMF), in particular, has devoted great attention to the question of the required institutions and practical details to make IT a suitable strategy, especially for less developed and emerging economies (Masson, Savastano, and Sharma 1997; Schaechter, Stone, and Zelmer 2000; Clinton et al. 2015). The importance of stable fiscal, monetary, and financial institutions for smoothing the impact of currency depreciation on banks' and companies' balance sheets and for preventing a sudden stop in foreign capital inflows has become a highlight of the debate on whether the exchange rate regime matters at all (Calvo and Mishkin 2003). The inclusion of such considerations in the debate has resulted in a very positive overall attitude towards IT. Although the literature recognizes controlled government spending and banks' sound risk exposures as prerequisites for independent monetary policy, it also admits that, because of its strong commitment to achieving the price stability goal, IT effectively brings about these very same necessary conditions (Amato and Gerlage 2002; Mishkin 2004, 11). Again, economists have turned the argument in such a way that neither in theory nor in practice could one find an obstacle to the widespread adoption of IT by central banks.

The discussion of the broader institutional setup surrounding IT has widened to include the exchange rate regime itself. The conventional view that IT necessarily implies the central bank's neglect for the exchange rate has been challenged, notably thanks to the prevalence of the so-called financial transmission channel. Often the distinctive feature of small open emerging economies is their high degree of currency and bank liability dollarization, which amplifies the effect of exchange rate volatility on real output and macrofinancial stability. Since central banks in emerging economies consider this liability dollarization as a serious source of vulnerability, they more often than not, and upon advice from economic theory, intervene in the foreign exchange markets in order to contain sharp movements in the exchange rate. This raises the question of the potential incompatibility of IT with the necessary reality of more or less frequent foreign exchange interventions.

The latest research has concluded that far from being incompatible with IT, foreign exchange interventions can enhance its efficacy. In 
the context of dollarization, in order to mitigate the currency risks, "exchange-rate-anchored IT produces much better results" (Buffie, Airaudo, and Zanna 2018, 182). Fundamentally, in that specific context the central bank is bound to pursue two objectives and must therefore have recourse to two policy instruments (ibid., 161). Although foreign exchange interventions might amplify inflation volatility, the more credible a central bank is, the narrower the tradeoff between reduced output and increased inflation volatility (Adler, Lama, and Medina 2019, 1). Finally, research from the IMF concludes that there might be plenty of good reasons for an IT central bank to intervene on the forex market: manage risks from currency mismatches, contain an exchange rate shock, support a weak interest rate transmission channel, build up official reserves, and buffer foreign capital flows to contain the credit cycle (Hofman et al. 2020). In spite of two potential costs, namely moral hazard due to the implicit public guarantee on private risky behavior and possibly confusing and deanchoring inflation expectations, the compatibility of IT with any exchange rate regime has been established de facto (ibid., 18).

The literature on the macroeconomic effects of IT skillfully explores different aspects of monetary policy and its impact on the economy. This literature review leads to two conclusions. First, most of the discussion has not focused on IT itself as a standalone policy, but rather on its broader effect in terms of observed changes in macroeconomic variables. From that perspective, it belongs more to the area of economic history than to the field of monetary theory. ${ }^{4}$ Second, whenever the findings reveal inconclusive data, they are depicted in a context of benevolent doubt. As a result, the studies

\footnotetext{
${ }^{4} \mathrm{~A}$ large part of the literature on the performance of IT belongs to the field of public policies evaluation and consists in the application of evaluation-specific econometric techniques to the outcomes of IT in a given economy during a given period. Evaluation has become extremely popular within public policy agencies at all levels, both ex ante, to justify, and ex post, to assess the impact of concrete policy interventions. Public authorities have developed evaluation from a mere accountability exercise into a crucial foundation of so-called evidence-based policymaking. It should be obvious that in its constant search to invalidate or confirm an assumed policy impact, policy evaluation denies that economic and social theory has something meaningful to say about the design and assessment of public policy. Evaluation is methodological positivism discovered by public agencies in search of existential justification.
} 
of IT exhibit a clear pro-IT bias that gives the perception that the dissimulated goal of IT literature is to legitimize and popularize the adoption of that strategy by central banks.

\section{Analytical Foundation of Inflation Targeting}

The intellectual roots and biases of IT have been highlighted above. IT builds upon the New Keynesian version of an aggregate supply and aggregate demand macroeconomic model. It admits that high inflation disturbs economic choices. Yet it considers virtuous a positive inflation rate and sees deflation as a danger. Since these conjectures have received their fair share of rational critique elsewhere, and as they do not form the core of IT, they will not be analyzed further. Here, the focus will be the question of what the analytical core of IT is. Two elements in particular make the essence of IT.

First, IT relies on a presumably stable relation between nominal interest rates and inflation. This same link between interest and inflation underpins the claim by its proponents that IT offers central banks a solution for exerting control over inflation. At the same time, the relation between monetary aggregates, i.e., money supply, and inflation is de facto denied due to the instability of money demand or of the so-called velocity of circulation. In other words, the nominal interest rate is presented as the single most important economic variable that brings a monetary economy into equilibrium and consequently provides a policy tool by which to change that equilibrium.

Although IT proponents avoid the notion of monetary equilibrium, this is precisely what they mean by the very frequently used concept of a "monetary anchor." Practically any publication on IT refers to it but without defining it clearly. The IT-controlled interest rate is sometimes meant to anchor inflation expectations: "One role for inflation targets is to provide an anchor or coordinating device for inflation expectations" (Debelle 1997, 17). At other times, the anchor refers to monetary policy only: "to bind its [the central bank's] policy to an intermediate target that serves as the monetary anchor for monetary policy" (Neumann and Hagen 2002, 145). Others consider IT to anchor the economy itself: "inflation targeting can confer some important advantages. It provides a nominal anchor 
for policy and the economy" (Bernanke and Mishkin 1997, 108). One explicit discussion on the "need for a nominal anchor" explores IT as a monetary system for the economy (Freedman and Laxton 2009, 8-11). It appears, therefore, that this "monetary anchor" function of IT is a crucial analytical foundation, which also represents a specific view of the monetary equilibrium of an economy.

The second essential element of IT is the conjecture that in a world of multiple currencies this "monetary anchor" is independent from the relative quality of the domestic money. The monetary equilibrium of the national economy and the influence that the domestic central bank can exert upon it relate exclusively to the interest rate. This assumption underlies all claims about the very possibility of an independent monetary policy, i.e., a policy that is capable of controlling domestic inflation. As noted above, researchers have noted lately that more often than not central banks in emerging economies pursue (sterilized) exchange rate interventions while following IT. These interventions have been presented as a matter of choosing to employ a second tool that actually enhances the impact of the independent monetary policy. The implication is that all central banks operate on an equal footing, irrespective of the relative quality of their products as perceived by money users. This very egalitarian approach to paper money and central banking allows IT proponents to advocate its adoption by any central bank.

The foundations of IT are at odds with the essential contribution to monetary theory of the Austrian school of economics. The next section focuses on two crucial analytical weaknesses of IT that seriously question both its theoretical justification and its fitness to the real world.

\section{THE ANALYTICAL PITFALLS OF INFLATION TARGETING}

The Austrian theory of money uniquely integrates monetary, or macroeconomic, and individual, or microeconomic, phenomena through the pathbreaking application of the concept of marginal utility to the monetary good itself. The resulting successful analytical apparatus is naturally the most fit to approach contemporary issues arising from the coexistence of multiples monies. 


\section{The Monetary Relation as the True Anchor of the Economy}

Money, as the most commonly used medium of exchange, derives its utility from its capacity to exchange against other goods in the future. The monetary good does not embed these specific services of intermediation technologically, in the way a piano, a book, or a hammer physically contain and determine their own specific services. Rather, the services of a given unit of money depend on the quantity of goods it could sell for, i.e., on its expected purchasing power at the moment of exchange. ${ }^{5}$ Consequently, individuals' demand to hold money is effectively a demand for "real" money balances. At higher monetary prices, a larger money balance provides the same monetary services as a smaller money balance at lower prices. Individuals value the "real" monetary services of a given stock of money based on the marginal utility of the relevant unit, as in the case of any other good. These individual valuations bring about society's aggregate demand to hold money, which contributes to the determination of all monetary prices: "It is demand, a subjective element whose intensity is entirely determined by value judgments, and not any objective fact, any power to bring about a certain effect, that plays a role in the formation of the market's exchange ratios" (Mises [1949] 1998, 397).

The supply of money is the other factor that plays a role in the determination of prices: "The purchasing power of money is determined by demand and supply, as is the case with the prices of all vendible goods and services" (ibid., 407). Supply of and demand for money interact through the so-called money relation that encompasses all markets. Indeed, as a universal medium of exchange, money exchanges against all other goods. Hence, the purchasing power of money is determined by the very same process that is behind all

\footnotetext{
${ }^{5}$ This point is crucial for establishing the social and individual optimality of any amount of money in the economy: "The services money renders are conditioned by the height of its purchasing power. Nobody wants to have in his cash holding a definite number of pieces of money or a definite weight of money; he wants to keep a cash holding of a definite amount of purchasing power. As the operation of the market tends to determine the final state of money's purchasing power at a height at which the supply of and the demand for money coincide, there can never be an excess or a deficiency of money" (Mises [1949] 1998, 418). This conclusion implies that monetary theory itself cannot provide a rationale for monetary policy, which is therefore necessarily rooted in nonmonetary considerations.
} 
goods' price formation. The valuation of consumer goods and the appraisement of producer goods occur concomitantly and through the same market exchanges that explain how the purchasing power of money forms and evolves. From that perspective, the monetary relation is the foundation of that general coordination process between individual actions that ensures the all-time clearing and equilibration of all markets (Salerno 2011, 181-97). ${ }^{6}$

This true anchor of all catallactic phenomena operates through continuous market exchanges based on Mises's crucial observation that "Nobody ever keeps more money than he wants to have as cash holding" (Mises [1949] 1998, 401). Whenever individuals find themselves in possession of excess cash holdings, as in the hypothetical case of a general increase in the money supply, they divert the surplus monetary units toward additional exchanges that bring about a tendency toward higher-than-otherwise prices. Should individuals feel a deficit in their cash balances, they will dump other goods and services on the market in an attempt to increase their monetary reserves, which puts in motion a tendency toward lower-thanotherwise prices. These price movements are actuated by concrete market exchanges that bring about a new distribution, and hence a different employment, of the resources in the economy. They come to an equilibrating halt when, at the updated price and ownership structure, the acting individuals consider their effective monetary holdings adequate to their respective demands and therefore take no further action to add to or subtract from their cash holdings.

The crucial point is that the money relation truly anchors the economy through actual individual actions of buying and selling. Given a stock of money or changes therein, individuals' demand for money relative to other goods is the determining factor of prices. From the point of view of the acting individual, the stock of money

\footnotetext{
${ }^{6}$ Mises called this the driving force of money: "While money can be thought of only in a changing economy, it is in itself an element of further changes. Every change in the economic data sets it in motion and makes it the driving force of new changes. Every shift in the mutual relation of the exchange ratios between the various nonmonetary goods not only brings about changes in production and in what is popularly called distribution, but also provokes changes in the money relation and thus further changes. Nothing can happen in the orbit of vendible goods without affecting the orbit of money, and all that happens in the orbit of money affects the orbit of commodities" (Mises [1949] 1998, 415).
} 
in his possession is merely an economic datum among others. The conscious effort, by means of market exchanges, to bring his stock of money in correspondence with his valuation-driven demand for monetary services drives the price formation mechanism, which is also a resource allocation mechanism. The description of money price formation as relying on the actuality and necessity of individuals' market actions produces a praxeological quantity theory of money, fully integrated with the marginal value theory.

Hence, it is the demand for money and individuals' purposeful buying and selling of goods and services, analytically referred to as the "real" cash balances doctrine, that bring about the nominal anchoring of the economy, to borrow the vocabulary of the inflation-targeting literature. In this framework, there can be no direct causal link between interest rates and inflation. If a relationship exists between these two variables, it is the money relation itself that brings it about. Knut Wicksell's attempt to relate interest rates to prices exemplifies this point amply. ${ }^{7}$ Wicksell was a convinced proponent of the classical version of the quantity theory of money: "Absolute prices on the other hand-money prices-are a matter in the last analysis of pure convention, depending on the choice of a standard of price which it lies within our own power to make" (Wicksell [1898] 1962, 4). ${ }^{8}$ Yet, when it comes to providing an account of actual price changes, the reference to individual actions becomes unavoidable:

Now let us suppose that for some reason or other commodity prices rise while the stock of money remains unchanged, or that the stock of money

\footnotetext{
${ }^{7}$ Beyond the specific contribution of Wicksell to this problem, the reference to him in this context is unavoidable because of Michael Woodford's explicit tribute to Wicksell in the very title of his modern, now authoritative, textbook on monetary theory, in advocacy of rule-based monetary policy (Woodford 2011).

${ }^{8}$ Consider also this more analytical passage on the dichotomy between relative and money prices: "It is then obvious that the fundamental conditions of exchange are not affected by the intervention of money.... So the function of money is here purely that of an intermediary; it comes to an end as soon as the exchange has been effected. Hence we arrive at an important, if self-evident, fact the neglect of which has constantly resulted in false conclusions. The exchange of commodities in itself, and the conditions of production and consumption on which it depends, affect only exchange values or relative prices: they can exert no direct influence whatever on the absolute level of money prices" (Wicksell [1898] 1962, 23; original emphasis).
} 
is diminished while prices remain temporarily unchanged. The cash balances will gradually appear to be too small in relation to the new level of prices.... I therefore seek to enlarge my balance.... The same is true of all other owners and consumers of commodities. But in fact nobody will succeed in realising the object at which each is aiming - to increase his cash balance; for the sum of individual cash balances is limited by the amount of the available stock of money, or rather is identical with it. On the other hand, the universal reduction in demand and increase in supply of commodities will necessarily bring about a continuous fall in all prices. This can only cease when prices have fallen to the level at which the cash balances are regarded as adequate. (ibid., 39-40)

In his dynamic explanation of the cumulative price changes triggered by discrepancies between the market and the normal interest rates, Wicksell refers to this same analytical device. Price changes, and hence inflation, are rooted in individuals' endeavors to equilibrate their demand for money to the supply thereof. In short, human action as regards the money relation brings about and regulates the social phenomenon of inflation.

This conclusion exposes four major deficiencies with the analytical foundation of the inflation-targeting framework. First, the explicit neglect of the demand for money and of monetary aggregates, on the ground that they are empirically unstable, is a fatal theoretical flaw. Fundamentally, it is a reflection of the classical dichotomized classification of economic phenomena into real and monetary areas. It is in this context only that one can think in conceptual categories such as aggregate demand for money or average velocity of circulation. Conscious of the related lack of realism, the proponents of inflation targeting propose to break the dichotomy through the integration of so-called microeconomic foundations into a formal aggregate model. However, this proposed alternative to the praxeological approach based on individuals' concrete actions is bound to fail precisely because it ignores the critical importance of the demand for money and relies instead on conceptual categories that cannot be identified in the real world. In other words, the replacement of the money relation by the inflation target as an alleged monetary anchor for the economy, and hence for policy, is intellectually bankrupt and illusionary.

Second, this analytical neglect for the money relation results in a mechanical, and even distorted, view of the relation between 
interest rates and inflation. Lower interest rates lead to inflation only to the extent that they trigger an increase in the money supply. By implication, a central bank can influence inflation through its control over the interbank refinancing rate only to the extent that it is effectively influencing bank credit policy. This point, which was evident for Wicksell and has become a hallmark of Austrian monetary theory, is either silenced or outright ignored by the proponents of inflation targeting: "With the aggregate demand channel, monetary policy affects aggregate demand, with a lag, via its effects on the short interest rate (and possibly on the availability of credit)" (Svensson 2000, 158; our emphasis). In fact, in modern economies bank credit expansion is the primary means to bring additional means of exchange into existence. At any level of nominal interest rates and irrespective of central bank-engineered changes, many other factors-e.g., minimum cofinancing by borrowers' own funds, minimum revenue requirements for borrowers, creditors' collateral evaluation, or return expectations-determine banks' willingness to extend and borrowers' readiness to take extra credit. Consequently, no direct mechanical relationship exists between interest rate changes and inflation.

Third, the money relation shows that inflation expectations influence actual inflation only through their effect on the demand for money. The anticipation of future price increases is tantamount to an expected decline in the marginal utility of money holders' balances relative to other goods. The subsequent tendency to lower the demand to hold money balances, through increased purchases of other goods, brings about the actual tendency for prices to increase. The sequence, speed and magnitude of the price increases are engendered by and depend on the additional exchanges made possible by the lowered demand for money. This realistic and theoretically consistent view contrasts patently with the mechanistic approach followed by IT proponents who ground the role of inflation expectations in the self-validating properties of rational expectations rather than in the causal relations produced by human action.

Fourth, the fact that money permeates all markets suggests that the policy emphasis on exclusively targeting consumer prices lacks theoretical foundation. Producer and asset prices, as well as the exchange rate of a money relative to other currencies, are equally important aspects of the general price structure in the economy. 
Depending on individuals' concrete preferences and market choices, a decline in the purchasing power of money may translate initially into higher producer prices, while consumer prices first remain broadly stable. The resulting differences in sectoral price spreads trigger a resource reallocation, which is an integral part of explaining the dynamics of business cycles. IT's narrow focus on consumer prices as the single meaningful manifestation of inflation conveys a very incomplete and therefore distorted view of the market process itself. ${ }^{9}$

\section{Relations Between Multiple Money Producers}

An important aspect of the contemporary monetary order is the coexistence of multiple fiat money producers, each of them enjoying a monopoly protected by legal tender laws upon territories that commonly, though not always, coincide with the national boundaries. This multitude of monies goes together with a diversity in their relative quality. This observation has important bearing on each central bank's capacity to conduct monetary policy on its own.

The monetary relation, again, best reveals the quality differences between fiat monies. In the absence of an international commodity money, such as gold, there arises the problem of financing trade between nations using different monies. One solution is to use one or a few of the national fiat monies for intermediating international exchanges. The international use of these originally national monies implies a substantial expansion beyond their national boundaries in the demand to hold them. This is reflected, for instance, in so-called international currencies being held in reserve by all central banks and by commercial banks worldwide. Thanks to this foreign demand, which grows with the expansion of international division

\footnotetext{
${ }^{9}$ Yet although lacking theoretical justification, this focus can be understood from the point of view of the self-interest of a monopolist money producer. Although many assets provide store-of-value services, there are few alternatives to the medium-of-exchange function of money. In fact, most such alternatives are other, foreign monies. This implies that changes in the money relation are most visible in asset price changes and in exchange rate movements, which appear more volatile than changes in consumer prices. Thus, a money producer who wants to convince people of the quality of his money would naturally insist upon measuring its purchasing power in terms of consumer prices.
} 
of labor and cooperation, the international currencies' purchasing power is strengthened, which in turn confirms their outstanding position. Hence, international monies are necessarily of better quality than the simply national fiat monies.

It appears, hence, that an international monetary order based on multiple fiat monies puts in place a particular dynamic of rivalry between central banks. The producers of international reserve currencies enjoy special privilege due to their significantly enlarged territory of use. Hence, the inflationary impact of any round of monetary expansion on the strictly national economy is diluted significantly. This allows the central banks that issue these currencies to be comparatively more expansionary, to follow a relatively more inflationary policy, and to benefit from practicing seigniorage abroad. ${ }^{10}$ The resulting rivalry between producers of international monies creates a tendency toward further centralization and domination with the view of expanding each money's territory of use. Fixed exchange rates, currency boards, and outright dollarization are effective means for achieving this goal and represent forms of de facto monetary imperialism.

In this system, which describes the present-day monetary order, the producers of strictly national monies appear effectively dominated. To the extent that the international transactions in goods and capital are free, they influence the domestic monetary conditions. In addition to having to hold the international currencies for their cross-border transactions, and despite legal tender laws, individuals enjoy some degree of freedom to allocate part or all of their money holdings toward the foreign currency at the expense of the domestic money. Thus, the unavoidable international currency holdings domestically and abroad imply that these national central banks do not have full control of the domestic money supply. In particular, the choice of currency composition in individuals' money holdings implies that the demand to hold the national money is influenced by its perceived relative quality. On one hand, a spontaneous tendency toward further dollarization triggers higher prices in domestic currency and a relative depreciation. On the other hand,

\footnotetext{
${ }^{10}$ Given that the production of fiat money is the political means of exploitation par excellence, this system of double-tier exploitation has aptly been called "monetary imperialism" (Hoppe 1990).
} 
a stronger demand for domestic money at the expense of foreign currency holdings induces the money producer to acquire the extra units of international reserve money in exchange for additional units of its own exclusively domestic money. Thus, the producers of strictly national monies have to intervene in the foreign exchange market depending on individual preferences with respect to the currency composition of money holdings. ${ }^{11}$ In all circumstances, the national-money central banks lose their autonomy and hence cannot exercise an independent monetary policy.

What sense, then, could one make of the advocacy of IT for emerging and developing economies, where the national money producers are in a dominated position? The striking fact of the current system of dominant international currencies and dominated national monies is its inherent instability. The very multiplicity of monies puts in motion a rivalrous environment between all central banks aiming to ensure that their product, whether strictly domestic or international, remains relatively attractive. To achieve this, the gradual loss in a money's purchasing power due to the regular expansion of its supply should not be greater than that of other monies. Otherwise, this could trigger a decline in the demand to hold that money, which would de facto reduce the extent of its use and could even compromise its particular standing as an international currency. Thus, it is in the common interest of all money producers to coordinate their monetary expansion with the view of avoiding disruptive changes in the relative quality of their products. The popularization of IT for all central banks, with its emphasis on a similar inflation rate for all economies, i.e., a similar loss of purchasing power for all monies, is best understood as such a coordination device.

\section{INFLATION TARGETING IN UKRAINE}

After communism in the East collapsed in 1989 and Ukraine gained independence from the Soviet Union in 1991, the ruling political

\footnotetext{
${ }^{11}$ The money holders need not be national residents only. Nonresident foreigners, especially if animated by speculative motives, play a crucial role. Thus, even though a strictly national money might have a geographically limited scope, it is still part of the global international money relation and in necessary economic competition with other national and international monies.
} 
elite, not without favorable public opinion sick with nostalgia, procrastinated in transitioning away from central planning. Ukrainian politicians refused to submit the allocation of resources to the discipline of international market competition. Instead, they tried to shelter and privilege the nascent cooperatives, allowed since 1987 and often politically connected, and to avoid socially painful reforms by maintaining the status quo of controlled prices and government subsidies (Havrylyshyn 2017, 63-64). This also included keeping a network of bilateral trade treaties at nonmarket exchange rates with the former Soviet republics at a time when the latter were already opening their economies to international competition. Thus, the misallocation of resources in Ukraine persisted and deepened until late 1994, when eventually price liberalization started (ibid., 90). ${ }^{12}$ Because of a corrupt and insider-biased privatization process that gave birth to a large number of oligarchs with monopolistic stakes in practically all sectors, ${ }^{13}$ the economy of Ukraine continued to lag behind its regional peers even during the reformist period of 1994-2000. Ten years after 1994, the gross domestic product (GDP) in dollars per capita was only 35 percent higher. During the same decade, the per capita GDP had increased by 54 percent in Russia, from an initial level two and a half times higher, and by 132 percent in Poland.${ }^{14}$ Recently, after two years of stagnation in 2011 and 2012, the real GDP contracted by a cumulative 15.7 percent in 2014 and 2015. After returning to modest though accelerating real growth that reached 3.2 percent in 2019, ${ }^{15}$ the nominal per capita GDP in Ukraine barely amounted to USD 3,660, i.e., slightly above one-fifth of the average for Central Europe and the Baltics.

Oligarchic monopolies, systematic encroachment on property rights, and delayed market reforms have contributed to an exceptionally low level of investment in Ukraine. Gross fixed capital

\footnotetext{
${ }^{12}$ Gas and electricity prices for households were not liberalized until 2019.

${ }^{13}$ Andrusiv et al. (2018) contains the clearest presentation of oligarchic interests by sector.

${ }^{14}$ World Bank National Accounts Data (GDP per capita current US\$, NY.GDP. PCAP.CD); accessed Feb. 8, 2021), https://databank.worldbank.org/reports.aspx? source $=2 \&$ series $=$ NY.GDP.PCAP.CD\&country=\#.

${ }^{15}$ Ukrstat (The Change of Gross Domestic Product, Volume, Archives; accessed Feb. 8, 2021), http://www.ukrstat.gov.ua/operativ/operativ2004/vvp/ind_vvp/ind_vvp_e/ arh_indvvp_e.html.
} 
formation averaged only 16.6 percent of GDP between 2009 and 2019, respectively 2.8 and 4.8 percentage points behind the economies of Poland and Russia. ${ }^{16}$ Investors from abroad have also shown little interest in Ukraine. The stock of foreign direct investment amounted to USD 1,186 per inhabitant in 2019, while it reached USD 7,373 and 4,024 in Poland and Russia, respectively. ${ }^{17}$ Although low levels of investment, along with high likelihood of misallocation, are the major cause of the delayed development of Ukraine, monetary factors have also contributed to the economic backwardness.

\section{Monetary Developments in Ukraine}

Initially a member of the rouble zone, the National Bank of Ukraine (NBU) introduced the karbovanets in January 1992. Presented as a "coupon" currency, the real function of the karbovanets was to withdraw the rouble from domestic transactions. The NBU succeeded in centralizing Ukrainians' rouble holdings, which provided the government with the reserves necessary for centrally planned international transactions. Later in that same year, the Central Bank of Russia refused to supply more roubles to the Ukrainian government, which would have used them to finance dubious subsidies and the general deficit of an unreformed state. ${ }^{18}$

\footnotetext{
${ }^{16}$ World Bank National Accounts Data (Gross fixed capital formation, \% of GDP, NE.GDI.FTOT.ZS; accessed Feb. 8, 2021), https://databank.worldbank.org/reports. aspx? source=2\&series=NE.GDI.FTOT.ZS\&country. The difference of 8 percentage points to Romania is even more striking.

${ }^{17}$ IMF International Financial Statistics (International Investment Position, Liabilities, Direct investment [BPM6], US Dollar; accessed on Feb. 8, 2021), https://data. imf.org/?sk=78748667-480d-45ce-9768-e3541d7b3932\&hide_uv=1. International official statistics estimate the 2019 population of Ukraine at 44.0 million, with the last fully-fledged census from 2001 showing 48.4 million inhabitants. A refined methodology from end-2019, also correcting for the regions outside government control (1.9 million in Crimea, 4.4 million in Donetsk, and 2.2 million in Luhansk), suggests that a more correct population figure would be 35.5 million. This would put foreign direct investment per head at USD 1,470, which does not alter the country comparison materially.

${ }^{18}$ Although the Russian government indeed started the policy of price liberalization about two years before Ukraine, the conflict was due ultimately to the choice of who the first beneficiary of any newly created money should be. Already in October 1992, the Russian central bank had stopped honoring some of the payments that the NBU had authorized and financed with its own credits. The split of the rouble
} 
Once the karbovanets had replaced the rouble completely, the Ukrainian government removed the domestic legal tender privilege of the rouble. The NBU discontinued converting the karbovanets into the rouble and started producing the karbovanets independently in the autumn of 1992. Naturally, this resulted in a very strong hyperinflationary episode that started later that same year and lasted through 1993. Because of the loss of purchasing power, the exchange rate of the karbovanets to the dollar depreciated from 120 in January 1992 to 17,000 in September 1993 (Harvylyshin, Miller, and Perraudin 1994, 391).

The regular and relatively high inflation during the following years, due to the continued monetary financing of unreformed and inefficient state-owned companies, was depleting the official international reserves. It is in this context that, eventually, the Ukrainian authorities recognized the need for a monetary reform and the NBU replaced the karbovanets with the modern hryvnia (UAH) in September 1996. The authorities attempted to gain the confidence of the money users with a peg to the US dollar at UAH 1.85. However, the NBU continued to inflate and revised the peg down to UAH 5.5 in 2000 , which implied an external devaluation by 66 percent. Since then, the monetary history of Ukraine has been marked by the uninterrupted depreciation of the hryvnia's purchasing power, exerting continuous pressure on the sustainability of the peg (see chart 1$).{ }^{19}$

zone into independent money producers (Ukraine left on November 12, 1992) provided the final solution to this conflict. Johnson and Ustenko (1993) provide very interesting details on the early post-1989 monetary history of Ukraine.

19 "Official hryvnia exchange rate against foreign currencies," National Bank of Ukraine, accessed on Feb. 8, 2021, https://bank.gov.ua/files/Exchange_r.xls and "Consumer Price Indices," National Bank of Ukraine, accessed on Feb. 8, 2021, https://bank.gov.ua/files/macro/CPI_y.xlsx. 
Chart 1. Cumulative internal and external depreciation of the hryvnia relative to the US dollar, 2000-19

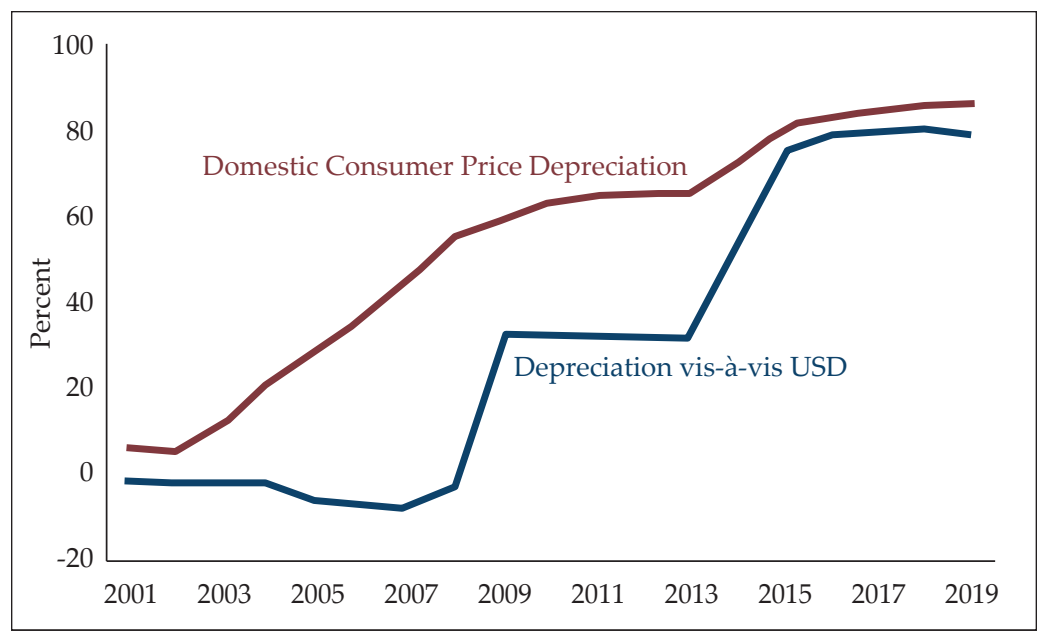

The devaluation of 2009 relative to the US dollar continued to lag behind the internal depreciation, despite the stability of consumer prices during the economic stagnation of 2011 and 2012. The NBU increased its holdings of government securities by 50 percent in 2013, triggering a 20 percent increase in the monetary base. The peg to the dollar was abandoned in early 2014, and after a further doubling of central bank credit to the government, official international reserves were almost depleted by end-2014 (see chart 2). ${ }^{20}$ By that time, the sizable external depreciation of the hryvnia had caught up with the cumulative loss of domestic purchasing power by 80 percent since 2000 . The floating exchange rate to the dollar has remained broadly stable around UAH 27 for the last five years.

20 "International Investment Position of Ukraine," National Bank of Ukraine, accessed on Feb. 8, 2021, https://bank.gov.ua/files/ES/IIP_y_en.xlsx. 
Chart 2. Official Ukrainian international reserves, 2000-19

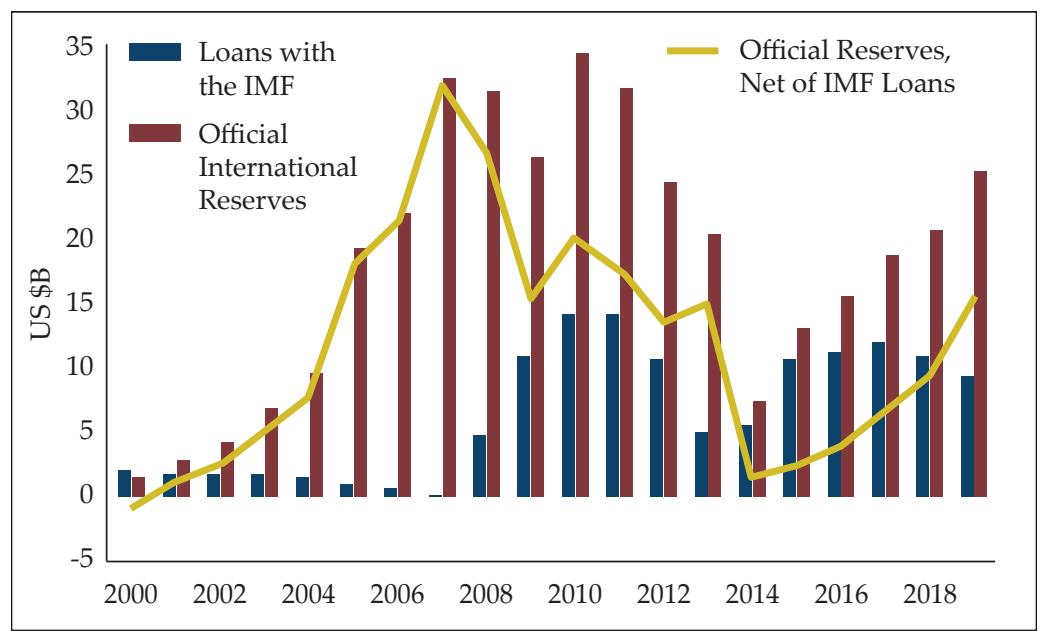

\section{The Ukrainian Experience with Inflation Targeting}

The National Bank of Ukraine decided and publicly announced in September 2015 that by end-2016 it would have a fully functioning inflation-targeting framework implemented. It set its inflation targets at $12 \pm 3 \%$ for end-2016, $8 \pm 2 \%$ for end-2017, 6 $\pm 2 \%$ for end-2018, and $5 \pm 1 \%$ for end-2019 and as medium-term objective beyond. Although the NBU had no difficulty in meeting the 2016 target, due to its largeness, it missed the targets for the next two years. Annual inflation remained close to 9 percent until the summer of 2019, when it started a steady decline to 1.7 percent in May 2020 before rebounding slowly to 2.5 percent in last August (see chart 3). ${ }^{21}$ Meanwhile, after cutting its policy interest rate by 350 basis points in the second half of 2019, the NBU embarked upon an even more aggressive policy and lowered its policy rate from 13.5 percent in December 2019 to 6 percent as of June 2020.

21 "Consumer price indices (to corresponding month of the previous year, \%)," National Bank of Ukraine, accessed on Feb. 8, 2021, https://bank.gov.ua/files/ macro/CPI_m.xlsx and "NBU Key Policy Rate," National Bank of Ukraine, accessed on Feb. 8, 2021, https://bank.gov.ua/en/monetary/stages/archive-rish. 
Arguably, although inflation targeting in Ukraine failed during its first three years, eventually it delivered on its medium-term target for a few months, before consistently missing the lower band of this target range. This raises the question of how much NBU policy contributed to that achievement and which factors ultimately kept inflation in, and below, the target zone.

Let us first examine the NBU's inflation forecasting and its relation to the policy interest rate. ${ }^{22}$ For end-2016, the NBU inflation forecast of 12 percent was very close to the actual rate of consumer price change of 12.4 percent. The NBU kept its end-2017 inflation forecast at 9.1 percent until July 2017. In line with this expected decline in inflation, the central bank cut its policy rate gradually from 22 percent in January 2016 to 12.5 percent in mid-2017. Contradicting the forecast, actual inflation started to accelerate in 2017. Faced with this reality, the NBU revised its end-of-year inflation forecast up to 12.2 percent, which eventually turned out to be 1.5 percentage points below the effective figure. It also initiated a cycle of rate hikes that lasted until April 2019. In October 2018, reality forced the NBU to again revise its initial inflation forecast of 8.9 percent to 10.1 percent, which turned out to be broadly correct, though outside the target range. Given its two-year record of undershooting forecasts, and the relative stability of actual inflation around 9 percent until August 2019, the NBU put its inflation forecast at 6.3 percent, i.e., slightly above the upper bound of the end-2019 target. The NBU started lowering its policy interest rate cautiously in April 2019 and accelerated the cuts beginning in September, when inflation began its decline. By August 2020, the inflation rate had been more than halved and sat below the lower band of the target, surprising all analysts. ${ }^{23}$ The NBU inflation forecasts for end-2020 remained somewhat volatile, though anchored within the target range.

${ }^{22}$ Data on the inflation forecasts by the NBU is extracted from the NBU quarterly "Inflation Reports," accessed on Feb. 8, 2021, https://bank.gov.ua/en/publications? page $=1 \&$ perPage $=5 \&$ search $=\&$ document $=\&$ pubCategory $=2 \&$ keywords $=\&$ created_from $=\&$ created_to $=$.

${ }^{23}$ The consumer price index hit the middle of the target range in December 2020. However, this appears to be an accidental development that is unlikely to remain a permanent achievement. 


\section{Chart 3. Inflation and NBU policy interest rate, January 2015-} December 2020

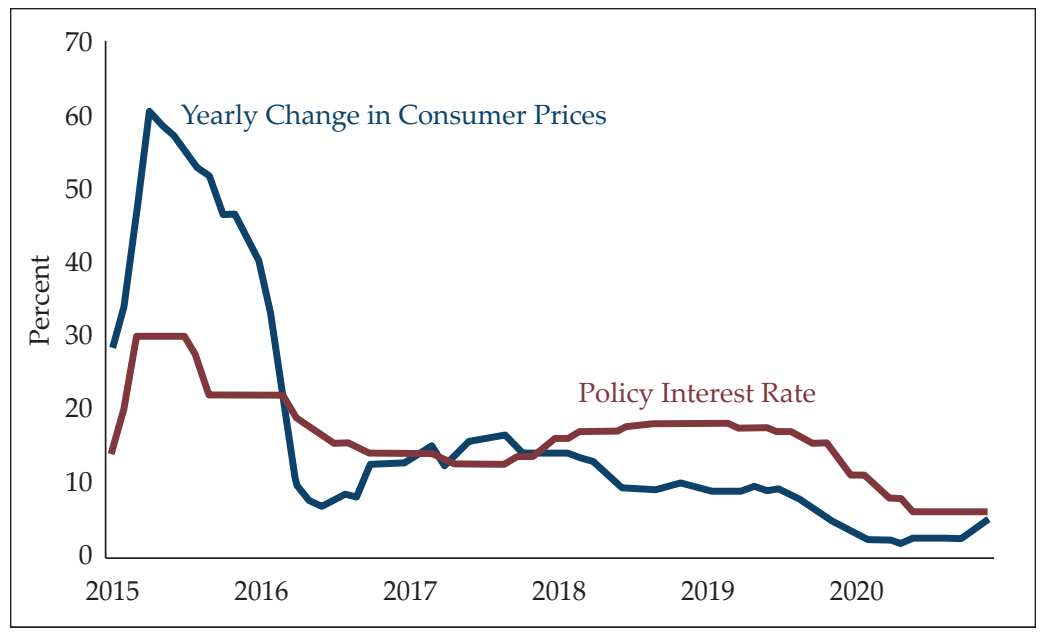

These developments invite two conclusions. First, the NBU is using a formal model that has failed to anticipate actual inflation within reasonable margins of error for the last three years. The only reason why the central bank did not adjust its forecast in October 2019 is that, at the time, the forecast looked correct as nobody foresaw that the decline in inflation would accelerate toward the end of the year. Second, there is no identifiable causal link between the inflation forecasts and the changes in the policy interest rate. Except for the October upward revisions, the NBU inflation forecasts have been on a systematic downward slope. The NBU lowered its policy rate until September 2017, increased it for the next twelve months, kept it constant between September 2018 and April 2019, and then decreased it afterward. Moves in the policy instrument do not appear motivated or even informed by the inflation forecasts. Rather, the NBU policy actions resemble more of a trial-and-error approach based on actual inflation developments. ${ }^{24}$

${ }^{24}$ The erratic nature of the NBU policy persists even with an assumed standard lag of four to six quarters between the policy interest and inflation. 
If we look now at the inflation expectations of market participants (see chart 4), ${ }^{25}$ they have been at odds with both actual inflation and the NBU forecast. Although financial analysts' expectations were somewhat closer to the NBU forecast, they had been undershooting actual inflation from 2016 until the summer of 2017 and failed to anticipate the disinflation from the second half of 2019. Households, i.e., money users themselves, were much more pessimistic than both financial experts and the reality itself for most of the period. ${ }^{26}$ Strikingly, households' inflation expectations, even though declining from above 20 percent to around 9 percent in mid-2019 and 7 percent in mid-2020, fell outside the NBU inflation forecast and even its inflation target. Thus, households deliberately ignored, or disagreed with, the central bank's policy announcements. Yet they did revise their expectations downward in line with realized inflation and possibly other factors. This is a sign that households had been increasing their confidence in the domestic money slowly yet gradually.

\section{Chart 4. Inflation expectations for the next twelve months, July 2015-December 2019}

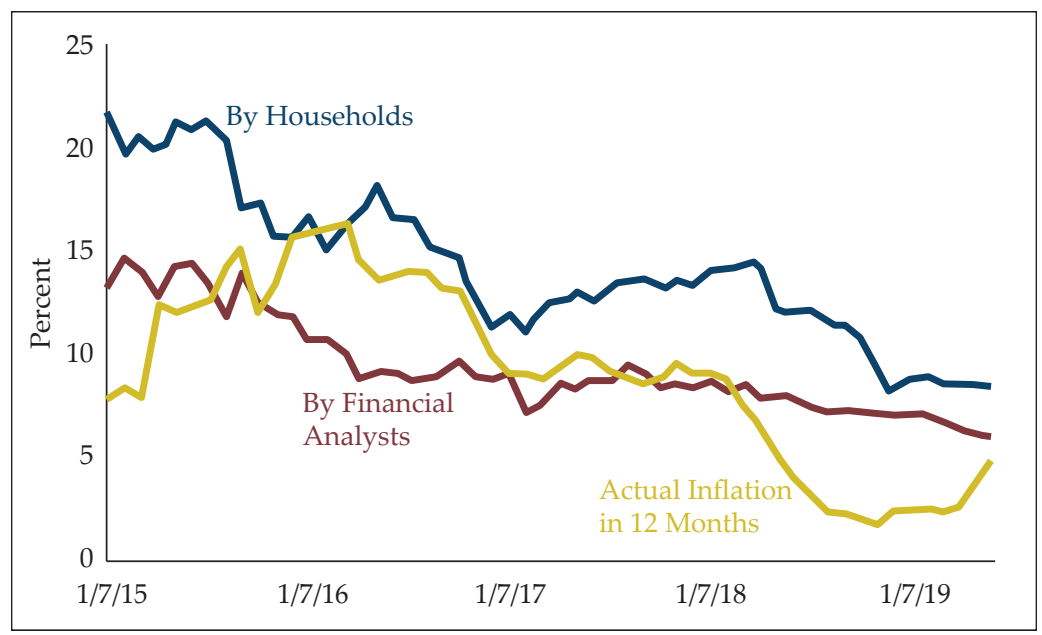

25 "Inflation expectations," National Bank of Ukraine, accessed on Feb. 8, 2021, https://bank.gov.ua/files/macro/Surveys_price.xlsx.

${ }^{26}$ This overshooting is probably due to Ukraine's long inflationary history and to households' having a different perception of the right measure of inflation. 
Though still short lived, the Ukrainian experience with IT offers enough insights to seriously question all of the framework's assumptions. First, there is no clear correlation between interest rate policy moves, inflation forecasts, and actual inflation. Second, money users' inflation expectations seem little influenced by official inflation forecasts. Third, the Ukrainian case does not confirm the presumed direct causal relationship between inflation expectations and inflation. Finally, the standard theory behind IT fails to account for the strong disinflation in the second half of 2019.

In fact, developments in the supply of money and the demand for money much better explain the changes in inflation since the formal introduction of IT in Ukraine. The growth rates of both base and broad money, as measured by the aggregate M3, declined steadily from 2016 to 2018 before rebounding in late 2019 (see Table 1). ${ }^{27}$ Interestingly enough, the expansion of base money, which is under stricter control by the central bank, had already accelerated in 2018, when the NBU increased its policy interest rate. This calls into question the very foundations of IT. Credit expansion, by both the central bank and the commercial banks, has abated even more strongly. More specifically, domestic credit, including in hryvnias, contracted in 2019, which is consistent with the rapid disinflation toward the end of that year and the low inflation in 2020.28

Table 1. Changes in money supply and in bank credit, 2016-19 (all figures are percentages)

\begin{tabular}{|l|l|l|l|l|}
\hline & $\begin{array}{l}\text { Base } \\
\text { Money }\end{array}$ & M3 & $\begin{array}{l}\text { Domestic Credit, } \\
\text { All Currencies }\end{array}$ & $\begin{array}{l}\text { Domestic Credit } \\
\text { in Hryvnias }\end{array}$ \\
\hline 2016 & 13.56 & 10.93 & 11.27 & 23.39 \\
\hline 2017 & 4.60 & 9.60 & 4.40 & 10.23 \\
\hline 2018 & 9.20 & 5.70 & 3.00 & 3.05 \\
\hline 2019 & 9.60 & 12.58 & -8.51 & -2.71 \\
\hline
\end{tabular}

27 "Surveys of Financial Corporations," National Bank of Ukraine, accessed on Feb. 8, 2021, https://bank.gov.ua/files/3.1-Monetary_Statistics_e.xlsx.

${ }^{28}$ Note that that the annual money supply growth rates have tripled by November 2020, which has contributed to the increase in consumer prices inflation as from December that year. 
Changes in the demand for money, which are not directly observable, are more difficult to fathom. Nevertheless, the very high degree of dollarization of the Ukrainian economy allows for a relative analysis of the residents' demand for the hryvnia, as opposed to their demand for foreign currency. From that perspective, a number of factors suggest that the demand for the hryvnia had been strengthening even prior to IT adoption and especially in late 2019. First, investments in currency and deposits abroad have been mostly stable since 2012, which suggests that dollarization has come to a halt. ${ }^{29}$ The ratio between estimated foreign currency cash held by residents and the monetary aggregate M3 has been declining steadily from 2.1 in 2015 to 1.5 in 2019. Second, over this same four-year period, the degree of dollarization of households' deposits diminished from 52.7 percent to 42.0 percent. ${ }^{30}$ The abating dollarization of the Ukrainian economy is a sign that demand for the domestic currency has been strengthening, thereby creating a tendency toward its relative appreciation in terms of both other goods and other monies.

The relative strengthening in the demand for the domestic currency accelerated in the second half of 2019 and resulted in the significant appreciation of the hryvnia compared to the dollar. Capital inflows from abroad, including into government debt, accelerated, causing the net foreign assets held by commercial banks to increase in the single year 2019 by more than in the previous four years. This substantial net inflow of foreign currency liquidity nourished a sustained demand for the hryvnia, which ultimately could be provided only by its monopolistic producer. Consequently, the NBU had to intervene more intensely in 2019 and made net foreign currency purchases in exchange for additional hryvnia in the amount of about USD 8 billion, which was

\footnotetext{
${ }^{29}$ According to NBU data on the international investment position of Ukraine (see footnote 22), investments in currency and deposits abroad reached USD 109.6 billion in 2012 (63 percent of GDP), then declined to USD 100.7 billion in 2016, and stabilized at USD 100.4 billion in 2019 (67 percent of GDP). Of these assets, the estimated holdings of foreign currency cash only were, respectively, USD 83.6 billion, USD 83.1 billion, and USD 88.6 billion.

30 "Deposits held with deposit-taking corporations (excluding National Bank of Ukraine)," National Bank of Ukraine, accessed on Feb. 8, 2021, https://bank.gov. ua/files/3.2-Deposits_e.xlsx.
} 
five and a half times more than in 2018 and eight times more than in 2017. ${ }^{31}$

This brings us to the last piece of evidence related to the Ukrainian experience with IT: the central bank's open market interventions. One feature of the supplying of base money by the NBU is particularly striking - the vast majority of open market interventions are foreign exchange based (see Table 2). ${ }^{32}$ For instance, in 2017 and 2018 interest rate-based operations accounted for 22.1 percent and 5.8 percent of all hryvnia liquidity supplied to commercial banks. In 2019, the central bank used its interest rate-based interventions to absorb liquidity by issuing more certificates of deposits while it lowered the policy interest rate. ${ }^{33}$ This data reveals that since the implementation of IT in Ukraine, the NBU's increased supplying of base money has been in response to banks' net aggregate supply of foreign currency, which turns out to be the main component of their demand for hryvnia, given the extent of dollarization and openness of the economy. The 2019 surge in the interbank demand for hryvnias in exchange for dollars corroborates the relative increase in the broad demand for the domestic currency discussed above and explains the sharp disinflation. Together, these factors lead toone conclusion - the NBUhas beenreacting and adapting its policy to the improved liquidity situation of banks as determined by their customers' transactions and the resulting enhanced demand for the domestic currency. This illustrates the analytical point that in a world of multiple rival currencies, individuals' demand to hold the domestic money effectively limits the capacity of the domestic central bank to conduct independent monetary policy.

\footnotetext{
31 "NBU currency interventions," National Bank of Ukraine, accessed on Feb. 8, 2021, https://bank.gov.ua/files/Finmarket/InterventionsResults_eng.xlsx.

32 "Current Data on Banking System Liquidity and Factors Affecting Liquidity," National Bank of Ukraine, accessed on Feb. 8, 2021, https://bank.gov.ua/files/ Arhiv_liquidity_eng.xlsx. The original file by the NBU presents the daily change in banks' reserves as the balancing item between open-market operations (interest-rate based and others) and the so-called autonomous absorbing factors (cash in circulation, the Single Treasury Account and others). The table rearranges these items from the economic perspective of changes in base money supply and demand, on an annual basis.

${ }^{33}$ In 2020, the first year in which most of the open market operations are interest-based, the main driving factor is the spectacular increase in the demand for cash, most likely driven by a robust precautionary attitude toward the uncertainty related to the COVID-19 lockdowns and other policies.
} 


\section{Table 2. Open market interventions by the National Bank of Ukraine and changes in the demand for base money, 2017-20}

\begin{tabular}{|l|l|l|l|l|l|l|l|}
\hline & \multicolumn{5}{|c|}{$\begin{array}{l}\text { Open Market } \\
\text { Interventions } \\
\text { Interest- }\end{array}$} & \multicolumn{5}{|c|}{$\begin{array}{l}\text { FX- } \\
\text { Demand for Base Money } \\
\begin{array}{l}\text { Millions } \\
\text { of } \\
\text { UAH }\end{array}\end{array}$} & $\begin{array}{l}\text { Rate } \\
\text { Based }\end{array}$ & and Others & TOTAL & Cash & $\begin{array}{l}\text { Banks' } \\
\text { Reserves }\end{array}$ & $\begin{array}{l}\text { Gov't } \\
\text { Deposit }\end{array}$ & Others \\
\hline 2017 & 6,883 & 24,215 & 31,098 & 20,487 & $-3,015$ & 13,160 & 466 \\
\hline 2018 & 2,152 & 35,175 & 37,327 & 38,575 & $-1,841$ & 2,875 & $-2,282$ \\
\hline 2019 & $-94,120$ & 193,668 & 99,549 & 24,922 & 16,783 & 63,947 & $-6,103$ \\
\hline 2020 & 50,275 & 20,730 & 71,005 & 133,344 & $-14,943$ & $-36,089$ & $-11,307$ \\
\hline
\end{tabular}

This review of Ukraine's recent experience with inflation targeting shows that monetary demand and supply factors have been the main drivers of inflation developments. Moreover, the changes in the supply of base money have not been autonomous; rather, they have accommodated respective and underlying changes in the domestic economy's demand for hryvnias relative to the US dollar. The central bank's open market operations, presumably directed by interest rate moves and geared toward the goals and targets of monetary policy, do not appear to be determined independently. Rather, they respond to changes in the demand for the domestic currency, in particular relative to foreign currencies. In short, the Ukrainian experience illustrates that the primary function of IT is to create the illusion of scientific control over money production and hence to legitimize modern central banking.

\section{CONCLUSION}

Over the last three decades, inflation targeting has evolved from a new tentative approach to setting monetary policy into an established authoritative wisdom, acclaimed by both academia and policymakers. This article has documented economists' endeavors to justify IT and disentangled its main principles and assumptions from the realistic and individualistic standpoint of monetary theory in the Austrian tradition. Although helpful for understanding IT in its specific historical context, this approach also allows for more 
general insights into contemporary developments in monetary analysis. In particular, IT can hardly be considered as belonging to monetary theory at all. Its excessive emphasis on formal optimizing models offers no new knowledge about the monetary relations in an economy. More specifically, IT commits two analytical blundersexcessively formalistic emphasis on the role of inflation expectations and total neglect for individuals' demand for money. In fact, the only meaningful way to integrate inflation expectations into the analysis of inflation would be through the demand for money, i.e., through individuals' revealed actions to hold more or less money. From that point of view, IT is definitely a failed intellectual attempt. Moreover, it supports a simplistic, mechanistic view of complex volitional social phenomena and hence contributes to veiling modern central banking with the mantle of expert scientism. Put briefly, it distorts impartial theory, subordinating it to interested policy. It builds up analytical illusions, because it aims at upholding the practical illusion of independent central banking.

The hollow content of IT naturally makes it unfit to properly explain real-world monetary developments. The recent experience of Ukraine provides an illustration. The empirical evidence does not support some of the main tenets of IT, such as a direct link between inflation expectations and inflation, congruence between official forecasts and the public's expectations, or even a perceptible directional link between official inflation forecasts and policy interest rate changes. Moreover, IT gives no useful insights into two striking features of the Ukrainian reality that a valid monetary theory should be able to account for. First, despite formally sticking to strict IT, the central bank in Ukraine has been intervening much more prominently in the foreign currency market, through exchange rate interventions, than in the domestic interbank market through interest rate operations. Second, rapid disinflation, which surprised all analysts and for which the central bank itself has claimed no merit, occurred in the last two quarters of 2019. Two essential elements of Austrian monetary theory, namely its emphasis on the demand to hold money as part of the all-permeating monetary relation and its insight into the nature of fiat monies and modern central banking, offer a compelling explanation for these two outcomes. This is evidence of the superiority of economic theory based on a realistic approach to human action in understanding inflation. 


\section{REFERENCES}

Adler, Gustavo, Ruy Lama, and Juan Pablo Medina. 2019. "Foreign Exchange Intervention and Inflation Targeting: The Role of Credibility." Journal of Economic Dynamics and Control 106: 1-20.

Adrian, Tobias, Douglas Laxton, and Maurice Obstfeld. 2018. "An Overview of Inflation-Forecast Targeting." In Advancing the Frontiers of Monetary Policy, edited by Tobias Adrian, Douglas Laxton, and Maurice Obstfeld, chapter 1. Washington, D.C.: International Monetary Fund.

Agénor, Pierre-Richard. 2000. “Monetary Policy under Flexible Exchange Rates: An Introduction to Inflation Targeting." World Bank Policy Research Working Paper 2511, Washington, D.C.

Amato, Jeffery, and Stefan Gerlach. 2002. "Inflation Targeting in Emerging Market and Transition Economies: Lessons after a Decade." European Economic Review 46: 781-90.

Andrusiv, Victor, Oleg Ustenko, Yurii Romanenko, and Ihar Tyshkevich. 2018. The Future of the Ukrainian Oligarchs. Kyiv, Ukraine: Ukrainian Institute for the Future.

Ball, Laurence, and Niamh Sheridan. 2003. "Does Inflation Targeting Matter?" IMF Working Paper WP/03/129, Washington, D.C., June.

Begg, David. 1982. The Rational Expectations Revolution in Macroeconomics. Baltimore: Johns Hopkins University Press.

Bernanke, Ben S., and Frederic S. Mishkin. 1997. "Inflation Targeting: A New Framework for Monetary Policy?" Journal of Economic Perspectives 11, no. 2: 97-116.

Buffie, Edward, M. Airaudo, and Felipe Zanna. 2018. "Inflation Targeting and Exchange Rate Management in Less Developed Countries." Journal of International Money and Finance 81: 159-84.

Calvo, Guillermo, and Frederic S. Mishkin. 2003. “The Mirage of Exchange Rate Regimes for Emerging Market Countries." Journal of Economic Perspectives 17, no. 4: 99-118.

Clinton, Kevin, Charles Freedman, Michel Juillard, Ondra Kamenik, Douglas Laxton, and Hou Wang. 2015. "Inflation-Forecast Targeting: Applying the Principle of Transparency." IMF Working Paper WP/15/132, Washington, D.C. 
Debelle, Guy. 1997. "Inflation Targeting in Practice." IMF Working Paper WP/97/35, Washington, D.C.

Freedman, Charles, and Douglas Laxton. 2009. "Why Inflation Targeting?" IMF Working Paper WP/09/86, Washington, D.C.

Friedman, Milton. 1968. "The Role of Monetary Policy." American Economic Review 58, no. 1: 1-17.

Frömmel, Tomas. 2019. "Negative Inflation Targeting: A Proposal of a Non-distortionary Monetary Policy." Quarterly Journal of Austrian Economics 22, no. 3: 336-56.

Gertchev, Nikolay. 2007. "A Critique of Adaptive and Rational Expectations." Quarterly Journal of Austrian Economics 10: 313-29.

Havrylyshyn, Oleh. 2017. The Political Economy of Independent Ukraine: Slow Starts, False Starts, and a Last Chance? London: Palgrave Macmillan.

Harvylyshin, Oleh, Marcus Miller, and William Perraudin. 1994. “Deficits, Inflation and the Political Economy of Ukraine." Economic Policy 9, no. 19: 353-401.

Hofman, David, Marcos Chamon, Pragyan Deb, Thomas Harjes, Umang Rawat, and Itaru Yamamoto. 2020. "Intervention under Inflation Targeting-When Could It Make Sense?" IMF Working Paper WP/20/9, Washington, D.C.

Hoppe, Hans-Hermann. 1990. “Banking, Nation States and International Politics: A Sociological Reconstruction of the Present Economic Order." Review of Austrian Economics 4: 55-87.

International Monetary Fund. 2018. Annual Report on Exchange Arrangements and Exchange Restrictions. Washington, D.C.: International Monetary Fund.

Johnson, Simon, and Oleg Ustenko. 1993. “Ukraine Slips into Hyperinflation." Washington, D.C.: National Council for Soviet and East European Research.

Kim, Junham. 2011. "Inflation Targeting as Constrained Discretion." Journal of Money, Credit and Banking 43, no. 7: 1505-22.

Kumhof, Michael, Shujing Li, and Isabel Yan. 2007. "Balance of Payments Crises under Inflation Targeting." IMF Working Paper WP/07/84, Washington, D.C. 
Kydland, Finn, and Edward Prescott. 1977. "Rules Rather Than Discretion: The Inconsistency of Optimal Plans." Journal of Political Economy 85, no. 3: 473-92.

Lee, Wang-Sheng. 2011. "Comparative Case Studies of the Effects of Inflation Targeting in Emerging Economies." Oxford Economic Papers 63, no. 2: 375-97.

Lucas, Robert E. 1972. "Expectations and the Neutrality of Money." Journal of Economic Theory 4: 103-24.

Masson, Paul, Miguel Savastano, and Sunil Sharma. 1997. "The Scope for Inflation Targeting in Developing Countries." IMF Working Paper WP/97/130, Washington, D.C.

Mises, Ludwig von. (1949) 1998. Human Action: A Treatise on Economics. Scholar's ed. Auburn, Ala.: Ludwig von Mises Institute.

Mishkin, Frederic S. 2004. "Can Inflation Targeting Work in Emerging Market Countries?” NBER Working Paper 10646, Cambridge, Mass.

Muth, John F. 1961. "Rational Expectations and the Theory of Price Movements." Econometrica 29, no. 3: 315-35.

Neumann, Manfred J. M., and Jürgen von Hagen. 2002. “Does Inflation Targeting Matter?" Federal Reserve Bank of St. Louis Review, July/ August 2002, 127-48.

Rose, Andrew. 2007. "A Stable International Monetary System Emerges: Inflation Targeting is Bretton Woods, Reversed." Journal of International Money and Finance 26: 663-81.

Rothbard, Murray N. (1962, 1970) 2009. Man, Economy and State, with Power and Market. 2d scholar's ed. Auburn, Ala.: Ludwig von Mises Institute.

Salerno, Joseph T. 2010. Money: Sound and Unsound. Auburn, Ala.: Ludwig von Mises Institute.

Sargent, Thomas, and Neil Wallace. 1975. "'Rational' Expectations, the Optimal Monetary Instrument, and the Optimal Monetary Supply Rule." Journal of Political Economy 83, no. 2: 241-54.

Schaechter, Andrea, Mark R. Stone, and Mark Zelmer. 2000. "Adopting Inflation Targeting: Practical Issues for Emerging Market Countries." IMF Occasional Paper 202, Washington, D.C. 
Svensson, Lars. 1997. "Exchange Rate Target or Inflation Target for Norway." In Choosing a Monetary Policy Target, edited by Anne Berit Christiansen and Jan Frederik Qvigstad, 120-38. Oslo, Norway: Scandinavian University Press.

— . 1999. "Inflation Targeting as a Monetary Policy Rule." Journal of Monetary Economics 43: 607-54.

_. 2000. "Open-Economy Inflation Targeting." Journal of International Economics 50: 155-83.

Wicksell, Knut. (1898) 1962. Interest and Prices: A Study of the Causes Regulating the Value of Money. Reprint, New York: Sentry Press.

Woodford, Michael. 2011. Interest and Prices: Foundations of a Theory of Monetary Policy. Princeton, N.J.: Princeton University Press. 